\title{
Regulation and Private Participation in the Water and Sanitation Sector
}

By JUDITH A. REES
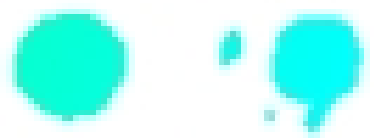

G lobal Water Partnership Technical Advisory Committee (TAC)

This brochure is printed on swan-marked paper.

The N ordic swan mark guides consumers to the most environmentally sound products. To acquire the swan symbol, producers must adhere to strict guidelines which are revised on an ongoing basis. This paper was produced according to these guidelines. 
G lobal Water Partnership (GW P), formally established in 1996, is an international network open to all organisations involved in water resources management: developed and developing country government institutions, agencies of the U nited $\mathrm{N}$ ations, bi- and multilateral development banks, professional associations, research institutions, nongovernmental organisations, and the private sector. GW P was created to foster Integrated W ater Resources M anagement (IWRM), which aims to ensure the coordinated development and management of water, land, and related resources by maximising economic and social welfare without compromising the sustainability of vital environmental systems.

GW P promotes IW RM by creating fora at global, regional, and national levels. The Partnership's governance includes the Technical Advisory Committee (TAC), a group of 12 internationally recognised professionals and scientists skilled in the different disciplines of water management. This committee, whose members come from different regions of the world, provides technical support and advice to the other governance arms and the Partnership as a whole. The TAC has been charged with developing an analytical framework of the water sector and proposing actions that will promote sustainable water resources management. The TAC maintains an open channel with its mirror bodies, the GW P regional TACS, currently being established around the world to facilitate application of IW RM regionally and nationally.

Worldwide adoption and application of IW RM requires changing the way business is conducted by the international water resources community, particularly the way investments are made. To effect changes of this nature and scope, a strategy that addresses the global, regional, and conceptual aspects and agendas of implementing actions is being employed. This series, published by GW P via its host institution - the Swedish International Development Cooperation Agency (Sida) - was created to disseminate the papers written and commissioned by the TAC to address the conceptual agenda. Issues and sub-issues within them, such as water for food security, privatisation, and the role of women in water management are addressed in the papers.

The findings, interpretations, and conclusions expressed within this series are entirely those of the author(s) and should not be attributed in any manner to GWP, Sida, nor as official expressions of the Global Water Partnership Technical Advisory Committee. This particular paper, Regulation and Private Participation in the Water and Sanitation Sector, was prepared by TAC member Judith A. Rees for the Committee's N ovember 1997 meeting in Vitória, Brazil. 
Regulation and Private Participation in the Water and Sanitation Sector 
(C) Global Water Partnership/Swedish International Development Cooperation Agency

S105-25 Stockholm, Sweden

All rights reserved.

Printed in Sweden.

First printing, July 1998.

Global Water Partnership gratefully acknowledges the permission of the author and of the United Nations to reprint this text, which was first published in Natural Resources Forum in May 1998, Volume 22, Number 2.

No use of this publication may be made for resale or other commercial purposes without prior written permission of the copyright holders. The findings, interpretations, and conclusions expressed within this publication are entirely those of the author and should not be attributed in any manner to GWP, Sida, nor as official expressions of the Global Water Partnership Technical Advisory Committee.

ISSN 1403-5324

ISBN $915867618 x$ 


\section{Regulation and Private Participation in the Water and Sanitation Sector}

\section{Judith A. Rees}

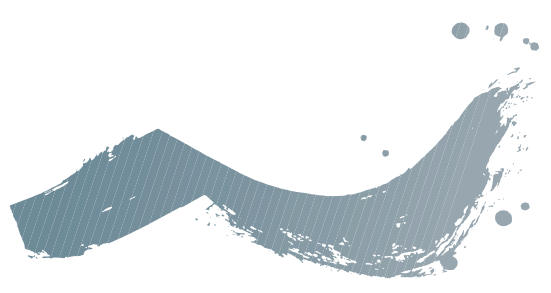

Published by the G lobal Water Partnership

The author is a member of the Global Water Partnership Technical Advisory

Committee (TAC) and a Professor of Environmental and Resource M anagement, Department of Geography and Environment, London School of Economics and Political Science. 


\section{ABSTRACT}

PrIVATE SECTOR PARTICIPATION is widely perceived to be the solution to the failure of many publicly owned and managed water utilities to operate efficiently and make the investments required to meet community needs. However, there are no guarantees that privatisation will actually yield the desired performance improvements. Simply converting a public sector monopoly into a private one provides no competitive incentives for the utility to operate efficiently, make appropriate investments or respond to consumer demands. Likewise, privatisation per se need do little to improve sector performance if governments are unwilling or unable to tackle such underlying problems as overmanning, uneconomic water pricing policies, financing the provision of public and merit goods, and restricting over-intrusive political intervention.

Given the characteristics of the water and sanitation sector it is inevitable that some form of continued public regulation of the private companies will be necessary. The regulatory burden can be reduced by adopting a competitive form of privatisation, choosing a more competitive sector structure and devising an appropriate regulatory regime. However, it has to be recognised that there will be a trade-off between making a venture attractive to private firms and introducing a notionally 'ideal' regulatory system. Regulation in practice is as much about creating the conditions under which private firms can operate effectively and efficiently as it is about protecting specific customer and public interests. 
rivatisation and deregulation have become, since the 1980s, popular solutions to the widely perceived failure of state enterprises, planners and regulators. Government owned manufacturing industry has been characterised as lacking innovation capacity and being unable to compete in world markets; public utilities have been seen as hopelessly overmanned, inefficient and incapable of providing even basic services to growing populations, while regulatory bureaucracies have been regarded as costly burdens on private sector enterprise.

These failures have commonly been attributed to the fact of government ownership or management per se. Detailed explanations of why this should be the case vary, but most analyses cite three interrelated factors:

- State organisations are insulated from the competitive incentives found within free labour, capital or product markets;

- State enterprises are exposed to short-term political interventions, struggles for political advantage and the demands of special interest groups (such as trade unions) for privileges;

- State firm managers can pursue their own utility rather than the public interest because the ultimate owners - the tax payers - have few effective mechanisms to signal their requirements or dissatisfaction with the management.

There is now extensive evidence from many countries suggesting that lack of competition and "inconsistent and sometimes unpredictable political direction" have limited the efficiency with which state enterprises operate (Parker, 1997).

\section{Will privatisation improve performance?}

It is invalid, however, to assume that performance improvements will automatically occur if these state enterprises are subject to some form of privatisation. Private sector involvement cannot of itself and by itself remove many of the barriers to efficiency which impede public sector operations. 
In the United Kingdom, where an extensive privatisation programme began in the early 1980s, a range of performance studies have all concluded that there is no automatic relationship between privatisation and productivity improvements (Yarrow, 1989; Bishop and Green, 1995; Martin and Parker, 1997). Although most (but not all) privatised firms have recorded gains in labour productivity, the results for total factor productivity have been described as "particularly disappointing and do not support the view that privatisation has led to a major improvement in terms of the use of all inputs" (Parker and Martin, 1997, p. 29). For some industries productivity gains were actually highest under public ownership in the years immediately preprivatisation, which raises the question of whether the mechanisms employed to achieve such gains can be effective without the privatisation threat. The assessments of UK experience not only serve as a warning against over euphoric expectations about the possible achievements of privatisation but also show quite clearly that private sector ownership or management is not necessarily the crucial determinant of future industry performance.

\section{Factors influencing the outcomes of privatisation}

It goes without saying that the scope for private participation to yield performance improvements will partly depend upon the way the current public sector enterprise is operating. Present productivity, technical expertise, managerial capacity, pricing and revenue collection practices, investment strategies and regulatory constraints will all affect what it is possible for any new owner or manager to achieve. However, whether this scope will be translated into actual and sustainable performance improvements will be determined by the complex interplay between four interrelated factors:

- The form of private involvement (e.g. divestment, BOT, concession, contract);

- The competitive structure of the sector and the way that this is likely to change over time;

- The type of private company involved - this includes its technical and managerial competence, the range of its operations (e.g. 
diversified conglomerate or single output firm), its operating scale (transnational, national or local) and the characteristics of its owners/major shareholders;

- The post-privatisation regulatory regime - this term is being used in the widest sense to include all the continuing roles of the public sector and the institutions (contracts, regulatory agencies, laws, market tools, etc.) employed to influence, provide incentives for or directly control private sector behaviour.

These factors do not operate independently of each other. The form of private involvement and the competitive market structure will both, for example, affect the roles the public sector will have to continue to fulfil. Likewise the nature and capacity of the post-privatisation regulatory regime will not only influence the type of private company (if any) attracted to the venture but may also place practical limits on the feasible forms of private involvement.

\section{Privatisation Involves a Complex Set of Choices}

IN THIS PAPER, it is argued that the privatisation process is not simply about changing the ownership or managerial characteristics of an industry. It involves making a complex set of choices about all the factors influencing sector performance and creating the conditions under which private involvement can yield the desired performance improvements. An attempt will be made to assess the way that different sets of choices (about the relative roles of the public and private sectors, form of privatisation, industry structure, and regulatory regime) are likely to affect the outcomes of private sector participation. It is clear that the impact of such choices will not be uniform; much will depend upon specific local socio-economic and political conditions. Moreover, it is evident that most governments will have a highly constrained range of choices; some options which would notionally be 'ideal' are ruled out as being politically or financially infeasible. Privatisation is always the art of the possible; some potential benefits will have to be sacrificed in order to get any benefits at all. 


\section{Regulation as a bargaining process}

Before looking at the different privatisation and regulatory options, attention will first be paid to why the water and sanitation sector raises particularly difficult problems for private company involvement. The different forms of private participation and the implications that each has for the continued role of the public sector will then be discussed. Also considered will be the post-privatisation structure of the sector because this will affect the profitability of the private operators, the competitive incentives they have for efficient operations and the need for direct public regulation. The focus of the paper will then finally shift to regulation itself. Regulation is seen not just as a negative set of rules, monitoring and policing arrangements, but as a bargaining process which has to strike a balance between providing private companies with the incentives to invest and operate efficiently and protecting the interests of other social and economic actors. When discussing regulation, it is necessary to go beyond the measures specifically designed to affect the behaviour of the service providers. Also important is the broader regulatory environment which affects operator productivity, profitability and their willingness to accept different levels of commercial risk. A key element in this broader environment is the way that the water resources of a country are managed and allocated between competing users and uses.

\section{The D ifficult Characteristics of the Water Sector}

THERE ARE FIVE important characteristics of the water and sanitation sector which make the involvement of private companies a particularly challenging venture:

- The level of natural monopoly and the lack of substitute products;

- $\quad$ The public and merit goods supplied by the sector;

- The crucial relationship between water infrastructure and urban/economic development; 
- The highly capital-intensive nature of the sector and the overwhelming presence of sunk costs, which increase private-sector risks;

- The multi-purpose and hydrologically interconnected nature of the water resource itself.

\section{Monopoly}

If the water sector is divided into distinct functions along the supply delivery and waste disposal chain (figure 1) only two segments - the construction of capacity and plumbing services - are naturally competitive. The distribution of supplies to individual properties and the subsequent removal of sewage are classic network monopolies. Bulk supply provision, water treatment and sewage treatment all normally

\section{Competitive Characteristics of Water Industry Functions}

Resource Allocation and U se Regulation . . . . . . Natural Monopoly per Hydrological Unit

Capacity Construction ................. Competitive

(including storage water treatment and

sewage treatment)

Bulk Supply Generation. . . . . . . . . . . . . . . O ligopolistic (in places monopolistic)

Bulk Supply Transmission. . . . . . . . . . . . . . Areal Monopolies

Water Treatment. . . . . . . . . . . . . . . . . . ' $n$ ' Local M onopolies (at best oligopolistic)

Local Supply Distribution. ... . . . . . . . . . . . 'n' Local M onopolies

Local Sewerage Network

and Interconnected Storm Water Network ..... . 'n' Local Monopolies

Sewerage Treatment. . . . . . . . . . . . . . . . . ' $n$ ' Local Monopolies (at best duopoly)

Appliance Sales, Plumbing Services. . . . . . . . Competitive (e.g. quality testing)

Figure 1. The water sector divided into distinct functions along the supply delivery and waste disposal chain. The distribution of water and removal of sewage are classic network monopolies; only the construction of production capacity and plumbing services are naturally competitive. 
enjoy spatial monopoly because of the high costs involved in transporting bulky water products. In other utilities, most obviously telecommunications and electricity, monopoly power is gradually being eroded by technological innovation and the development of competitive substitutes. Such an erosion is unlikely to occur to any significant extent in the water sector at least in the foreseeable future. Monopoly is, in other words, likely to remain a long-term feature of water and sanitation services.

It is frequently forgotten that market failure and the difficulties involved in protecting the consumer from private monopoly power abuses were important factors historically in the development of public water utilities in many countries. The fact that these public utilities may have failed to deliver the required services, does nothing to change the basic monopoly problem. Evidence suggests that the performance of privatised industries is critically affected by the level of competition they face (Bishop and Green, 1995). There is no reason why private monopolies should be any more efficient or responsive to customer demands than public ones. They need not employ least-cost production methods, may have few incentives to innovate and will not necessarily provide the quantity or quality of water products for which customers are willing and able to pay.

It is well known that in unregulated private monopolies, output volumes, standards of service and investment levels will all be lower than under competitive conditions, while prices are likely to be higher and set to discriminate against customers with inelastic demands for water (Herrington and Price, 1987). As Parker (1997) has recently pointed out a "privately-owned monopoly is not an attractive outcome, particularly in industries providing basic consumer services (e.g. water and sewerage services) and where the price elasticity of demand (the responsiveness of consumer demand to price) is low" (p. 1).

In reality unregulated private monopoly is simply not an acceptable proposition in the water sector. This raises two important questions:

- What measures can be taken to limit monopoly power and subject the companies involved to competitive pressures? 
- How far is it possible to ensure that governments are any better at regulating private operators than they were as direct service providers?

\section{Public goods and social functions}

Water and sanitation services characteristically involve the provision of so-called 'public' and 'merit' goods. The former are goods and services which provide benefits to communities in general rather than to specific individual consumers; the public health and environmental benefits from sewage transportation, treatment and safe disposal are an obvious example. Merit goods are those which a particular society considers should be provided irrespective of whether individual consumers are willing and able to pay for them. Public health and humanitarian considerations, not to mention political imperatives, may, for instance, require that low income households or those living in very high provision cost areas receive affordable, subsidized services.

In those countries where the public sector has been unwilling or unable to finance socially beneficial investments in sanitation and sewage treatment or to ensure that the poor have access to essential supplies of clean water, private sector participation by itself is not the answer. Private companies are not social services. They will only provide public goods or below cost water supplies if they can recover the costs involved, including their required return on any investments made. Excluding foreign grant aid, such costs can only be recouped directly from the public purse or from general increases in water charges. In other words, privatisation has to be accompanied by explicit changes in pricing policies and/or public expenditure priorities.

\section{Water infrastructure and development}

Industrial, commercial and housing developments are clearly crucially dependent on the provision of new water infrastructure and on the maintenance of existing systems in operating order. It is by no means always the case that the profit-maximizing behaviour of private companies will result in the scale, location and timing of expenditure on infrastructure which best meets public needs. An obvious example arises when private companies are operating under time limited contracts. Towards the end of the term, it could well be in the financial 
interests of companies to allow conditions to deteriorate and to neglect capital investments.

Given the developmental importance of water, governments will inevitably want to ensure that private expenditure decisions reflect changing public priorities and are responsive to alterations in economic and social conditions. This creates quite taxing problems for both the initial design of private participation arrangements and for the development of regulatory systems. A delicate balance has to be struck between protecting the public interest while also protecting the companies from shifting and unrealistic demands for additional expenditure.

\section{C apital intensity, sunk costs and risk}

Although not all forms of privatisation involve the private partners in accepting responsibility for major capital investments, one of the most common reasons for privatisation is to relieve the public exchequer from the burden of meeting the very large investment needs of the water and sanitation sector. This reason was certainly of critical importance when the water industry was privatised in England and Wales; major expenditures were required to renovate existing systems and meet European Union water quality and environmental requirements (Rees, 1989). It is an even more pertinent factor in countries experiencing rapid urban and economic growth and endeavouring to extend the coverage of water and sanitation provision to a greater proportion of the population.

For the private sector large scale investments always involve significant risks and particularly so when the assets are sunk, i.e. they cannot be removed for use elsewhere or redeployed on site for other purposes. If an airline operator fails to make an acceptable return on investment, the aircraft may be used in other markets or sold to another operator; likewise most factories can be adapted to produce different goods if the initial venture proves unprofitable. Such options are largely unavailable in the water sector; there are no obvious alternative uses for the sewerage system or sewage treatment plants.

Risk comes in a variety of forms:

- Construction risk (the costs of new developments or system renovation exceed expectations; 
- Commercial risks (the demand for products change or new competitors enter the market);

- Financial risks (interest rates on borrowed capital rise or exchange rates shift);

- Regulatory risks (regulators alter standards of service require ments, refuse price rises or fail to prevent the pollution of water sources);

- Political risks (political instability, asset expropriation or expulsion from the country).

The more risk there is perceived to be, the higher will be the return on capital required by the private sector. This basic reality means that some countries (or individual municipalities) will simply be unable to find a willing investor because the market or political conditions are too unfavourable. In other cases, investors may be deterred by the lack of reliable information on existing asset conditions; this can be a particularly difficult problem for water distribution and sewerage services where assets are buried and not easily inspected.

Elsewhere success in attracting private investment at an acceptable cost to the economy (i.e. at a reasonable rate of return on the invested capital) will heavily depend upon what governments do to reduce private sector exposure to risk. This can often mean difficult trade-off situations. For example, commercial risks are cut if the companies are allowed a large spatial monopoly and exclusive rights to provide the whole range of services from bulk supply to sewage treatment. However, this means that governments have to forego the potential efficiency advantages of more competitive arrangements and accept the problems of protecting the public from potential monopoly abuse. Likewise, construction and regulatory risks can be reduced by guaranteeing full cost recovery if unanticipated construction or renovation problems are encountered or if new obligations are placed on the company. The problem is that such guarantees can remove incentives for least cost operations.

Regulatory risks can be further reduced by strictly limiting regulatory discretion or by giving a regulator the duty to ensure that the 
private companies can finance their activities (as in England and Wales). Risks can also be taken out of the business by removing, prior to privatisation, some of the barriers to profitability which exist in the public sector enterprise. For example, excess labour problems could be reduced by generous redundancy packages, but clearly such barrier removal may be expensive in both financial and political terms.

None of the decisions to protect the private companies from risk are free of cost. However, the bottom line is that companies will only invest in the water and sewage sector if risk and uncertainty are kept to acceptable levels.

\section{Water as a resource}

It is impossible to divorce consideration of water and sanitation services from questions about how water resources are managed. Water is a flow resource, occurring within hydrologically interconnected systems; change in one part of the system tends to set up chain reactions affecting the availability, quality and cost of supplies elsewhere within the water region. Governments will want to ensure that private company operations do not impose unacceptable externality costs on other resource uses (by, for example, depleting underground aquifers or polluting the drinking water sources of downstream users). Moreover, governments will want to make sure that current practices do not compromise the ability of the water system to provide essential supply and ecological functions in the future.

However, the private companies will also want assurances that the water resources law and any resource allocation or environmental agencies are capable of protecting them from the activities of upstream water and land users. Most obviously, they will want to ensure that their basic raw material remains available and of an acceptable (and predictable) quality. This can often mean that serious attempts to secure private involvement in water and sanitation have to be accompanied by reviews, and where appropriate reform, of a country's water resources law and resource allocation mechanisms. This is not a trivial nor uncomplicated exercise. 


\section{Private-Sector Involvement}

\section{FULL DIVESTITURE}

Full transfer of assets to private sector through asset sales, share sales or management buyouts. Private sector responsible for all capital investment, maintenance, operations and revenue collection.

\section{PARTIAL DIVESTITURE}

Government sells a proportion of shares in a 'corporatised' enterprise or creates a new joint venture company with the private sector.

\section{CONCESSION}

Government lets a long-term contract, usually over 25 years, to a private company, which is responsible for all capital investment, operations and maintenance. The assets themselves remain public sector property.

\section{LEASE}

Long-term contract (usually 10-20 years but can be longer). Private sector responsible for operations and maintenance and sometimes for asset renewals. Assets remain in public sector and major capital investment is a public responsibility.

BOT (Build-O perate-Transfer)/BO O (Build, O perate and O wn) Contracts are issued for the construction of specific items of infrastructure, such as a bulk supply reservoir or treatment plant. N ormally, the private sector is responsible for all capital investment and owns the assets until transferred to the public sector, but in BO 0 schemes, private ownership is retained.

\section{MANAGEMENT CONTRACT}

Short-term contracts, typically five years. Private firm only responsible for operations and maintenance.

SERVICE CONTRACT - [BUYING IN]

Single function contracts to perform a specific service for a fee, e.g. install meters.

Figure 2. Forms of private-sector involvement. 


\section{Forms of Privatisation}

THE TERM PRIVATISATION has been employed to cover a wide range of measures designed to improve the management of publicly owned enterprises (e.g. market testing or allowing access to private money markets). However, it is used here more narrowly to refer only to cases when governments physically transfer assets into private hands or contract the private sector to provide goods or services previously supplied by public bodies. Even within this more confined definition, the range of options is wide (figure 2, p. 15). The degree to which assets, responsibilities and functions are transferred to the private sector varies markedly, as does the nature of the accompanying regulatory regime.

\section{Divestment}

Divestment transfers the ownership of infrastructure assets into private hands as well as giving the private companies responsibility for all operations, maintenance, revenue raising and investment. This has not been a popular option in the water and sanitation sector despite the fact that there has been a long history of asset owning private operators in the United States and the United Kingdom. ${ }^{1}$ Only two cases of divestment are known to have taken place - the flotation of the water utilities in England and Wales and the very recent sale of $51 \%$ of the shares in Thailand's East Water bulk supply company (Hoare Govett Asia Ltd, 1997). The special characteristics of the water sector, discussed previously, mean that divestment would need to be accompanied by the creation of a system of continued public regulation. The more monopoly power and functional responsibilities the new companies have, the more comprehensive are the regulatory needs. As figure 3 shows, the water utilities in England and Wales have major constraints on their activities which would not apply to normal private companies.

\section{Concessions - a superior option?}

Rejection of the divestment option frequently has more to do with ideology and politics than with its economic or regulatory disadvan-

1. Private water suppliers, regulated by statute, were responsible for $25 \%$ of piped water supplies in England and Wales long before the 1989 privitisation of the water and sewage utilities. 


\section{Regulation and the Water Utility Companies in England and Wales}

\begin{tabular}{l|c|c}
\hline Management Freedom & WUCs & Normal PIcs \\
\hline To set prices & Constrained & Free \\
To decide and vary investment & Constrained & Free \\
To decide which raw material sources to develop & Constrained & Free \\
To decide which services/products to provide & Constrained & Free \\
To vary service quality & Constrained & Free \\
To refuse supply & Constrained & Free \\
To merge, divest and restructure & Constrained & Free \\
To dispose of assets & Constrained & Free \\
To go bankrupt & Most unlikely & Possible \\
\hline
\end{tabular}

Figure 3. Major constraints on the activities of water utilities in England and Wales that do not apply to normal private companies. 
tages when compared to concessions. Under a concession the sector assets formally remain public property. But during the concession period (normally $25-30$ years but can be over 50 years) a private company has exclusive usage rights over the assets and has complete responsibility for operations, system maintenance and new investments. In terms, then, of the functional responsibilities of the private sector there is little practical difference between divestment and concession. There are also, in reality, minimal differences between the two options in the regulatory tasks which need to be performed (see figure 4, p. 22).

It is conventional to claim that the concession system has two key features which make it a superior option. First, it introduces competitive incentives for efficiency since companies (normally but not universally) bid against each other to win the concession contracts. Second, it reduces the regulatory burden on government agencies by using the contract itself as the chief regulatory mechanism. Both of these claimed sources of superiority need to be viewed with some caution.

Bidding for concession contracts may result in short-term efficiency gains if genuine, free and fair competition actually occurs. Experience would suggest, however, that competition may be restricted by the dominance of a very small group of major companies in the international concessions market. These frequently form risk spreading consortia to win major contracts and may simply not take part in competitive bidding for smaller contracts. It is by no means unknown for a concession grantor to receive only one bid. In France, the home of the concession system, it has also been suggested that competition is restricted when contracts are rebid because the incumbent company has 'insider' knowledge and thus a higher chance of retaining the contract.

Whatever the initial gains from competition for the contract, these could be short-lived unless some regulatory mechanisms exist to curb the tendency towards economic inefficiency inherent in monopolies. By its nature, the concession explicitly creates an absolute monopoly and protects the concessionaire from most forms of competition. Although contracts lay down explicit performance targets, mechanisms for price adjustments and standards of service requirements, it is a simplification to assume that the state's role can be confined to monitoring company performance against the contract conditions. It is 
impossible to predict changing economic, social and technical conditions over a 20-30 year period and incorporate these within contract terms. Contracts have to be renegotiated frequently and without the benefits of competition, which imposes a not insignificant regulatory burden. The Buenos Aires concession was, for instance, renegotiated barely a year after the initial award (Idelovitch and Ringskog, 1995). Moreover, mechanisms need to be in place to ensure that companies are responsive to customer demands, do not resort to discriminatory pricing practices and have incentives to provide a good value service. In France, the local 'regulators' (municipal mayors) and the fact that the companies need to protect their reputation if they wish to win contracts in other municipalities, help restrict potential monopoly power abuses. Where such conditions do not apply, more formal public scrutiny and consultation mechanisms will be needed.

\section{Could divestment be an appropriate option?}

There are situations where divestment may have advantages over the concession. First, share sales could allow employees, customers and other local interests to acquire a stake in their water company, which may help ensure it operates effectively to meet local needs. Second, share sales or management buyouts could help develop indigenous private sector companies rather than relying on the 'foreign' conglomerates, which typically dominate the concession market. Third, in rapidly changing socio-economic conditions the inflexibility of concession contracts can be a major barrier to responsive innovation behaviour.

It is also worth noting that asset owning private companies are not protected from all forms of competition. Under-performance or excess profits could attract take-over interest, so called capital market competition (Littlechild, 1986), and the companies may also be subject to competition from new entrants. The divestment option is likely to have the best chance of being effective in countries where the public water and sanitation services have technically competent staff, other private companies exist with experience of providing infrastructural services (e.g. power) and where local/national financial markets are reasonably well-developed. 


\section{BOT options}

BOT (Build, Operate and Transfer) schemes and their variants are designed to attract private investment into the construction of new major items of infrastructure, such as bulk supply reservoirs, water or sewage treatment plants. Like concessions, BOT schemes introduce some competitive incentives for efficiency as companies normally compete to win the contracts. However, these gains can be eroded if specifications are changed after the contracts are let - the renegotiated terms are not competitively set. Moreover, efficiency incentives can decrease markedly if, in order to attract the desired investment, it is necessary to reduce private construction and commercial risks by providing cost overrun guarantees and onerous take or pay arrangements (the public sector is bound to pay for set quantities of water or sewage treatment irrespective of actual demands).

\section{Leases and management contracts}

None of the other forms of private sector involvement are designed to provide private capital for new water and sanitation infrastructure, although under leasing arrangement (the French affermage system), companies would be responsible for network maintenance, which could involve significant expenditure. Leases are normally competitively let and because of their more limited scope they are usually simpler to regulate than concessions or divestment. Where existing public suppliers have low productivities and poor revenue collection records, leases can be an effective option. However, much will depend on the contract terms and the system of economic regulation incorporated within the contract. Most lease contracts reduce commercial and regulatory risks by guaranteeing that allowable price rises will cover all cost of service increases. Such price guarantees do have the major advantage of curbing the political manipulation of water charges, which has so badly affected the financial viability of many publicly managed water enterprises. However, they do reduce the pressure on private companies to provide services at least cost. Moreover, where the leaseholder is part of a diversified conglomerate, problems of transfer pricing may well arise. ${ }^{2}$

2. "Transfer pricing" refers to situations whereby the costs of services provided by subsidiary or sister companies are not set by market forces but are established administratively within an integrated business to maximize total profits 
Management and service contracts are potentially the most competitive form of privatisation and impose the least regulatory burden. Since contracts are let at relatively short intervals, the private firms are under almost continuous pressure to cut costs. Moreover, as the functions transferred to the private sector are limited, barriers to entry into the business are likely to be fairly low; this is particularly so for service contracts where a potentially large group of firms would have, for example, the skills and resources to fit water meters or renovate a stretch of pipeline. One difficulty with contracting, however, is the tendency to accept the lowest bid for the work without taking sufficient account of the company's ability (or commitment) to provide an acceptable quality of service. Where the contract involves underground assets it is often difficult to monitor performance quality, and the effects of shoddy work may not become evident during the contract period.

Short-term management or service contracts clearly cannot help tackle the huge investment backlogs common in many rapidly developing and urbanising countries. Moreover, their effectiveness in improving operating performance can be limited if the public sector fails to provide the capital resources needed to renovate water treatment plants or distribution systems. In addition, where the problems of the sector have been caused, or exacerbated, by inconsistent political intervention, contracting may do little to distance the utility operator from such political interference. However, contracts can be a good way of achieving technology transfer and acquiring technical or managerial capacity.

\section{Industry Structure, Competitive Potential and Regulatory Burdens}

AS ALREADY DISCUSSED, most segments of the water and sanitation business are monopolistic; it is therefore difficult to generate much 'in- the-market' competition. While it is possible to introduce some competition for the market by choosing a form of privatisation involving bidding for contracts, the use of other market (or market-like) incentives depends on the structure of the sector in which the private firms will operate (figure 5, p. 28). Economists have also long argued that sector structure has an important bearing on the regulatory burden which the public sector must carry to protect customer interests. 


\section{Regulation and Customer Protection}

\section{Regulatory Tasks}

Price control

Promotion of operating efficiency

Service standard specification and monitoring

Control of externalities

Maintenance of public good functions

Ensure asset serviceability over time

Ensure development of essential infrastructure

Controls over powers to manipulate land values/land speculation

Controls over unfair trading practices

Safety net regulations

Promote water use efficiency

Ensure responsiveness to final customer needs

\section{O \& M Lease Concession BOT Divestment}

-

\begin{tabular}{l|l}
- & $V$ \\
- & $V$
\end{tabular}

$\checkmark$ V

I

$\checkmark-Y$
-

$\checkmark$

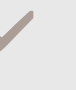

$\sqrt{2}$

$>1$

$\checkmark$
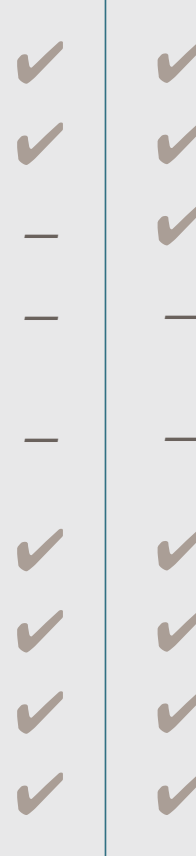$$
\checkmark
$$

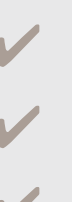

-

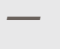

$\checkmark$

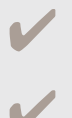

.

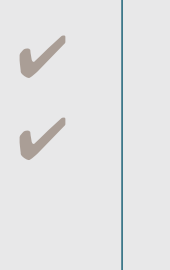

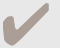
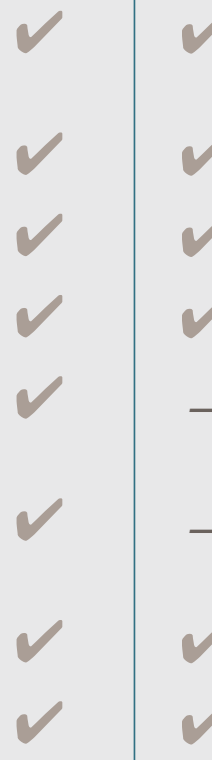

(possibly)

$-$

Figure 4. List of major regulatory tasks needed to ensure various forms of customer protection under privatisation. 


\section{The competitive and regulatory advantages of disaggregated industry structures}

From a competitive and regulatory point of view the water and sanitation industry should be vertically disaggregated (separate companies for each service function - bulk water supply, water distribution, sewerage, sewage treatment) and horizontally disaggregated (each firm serving a relatively small spatial area). With disaggregation, three advantages should, at least theoretically, arise. First, 'boundary' (entry) competition is facilitated. A neighbouring water supply company may, for example, be able to take customers away from an under-performing firm or one which is abusing its monopoly power by charging excessive prices. In practice, even where the legislative framework allows, and regulatory agencies are keen to promote this form of competition, it has proved remarkably difficult to achieve. It was, for example, only in May 1997 that the first case of a commercial user switching water supplier took place in England and Wales (OfWat, 28 May 1997). While the possibility of losing customers may act as a spur to better performance, there are problems involved in encouraging such competition. Private investors may simply not be attracted to situations where there is this source of commercial risk. In addition, 'cream skimming' could result in increased costs and prices for most customers. Cream skimming occurs when a competitor takes away customers (usually large industrial plants) which are cheap to supply, so leaving the incumbent company with high provision cost users and the burden of costly excess capacity.

Clearly for bulky commodities, like water and sewage, which need specially constructed and costly transport systems, boundary competition is limited by geography unless common carriage arrangements are in place; these allow one company to use another firm's pipes, for a fee, to deliver water (or even receive sewage or trade effluent for treatment). With common carriage the scope for competition may be increased but so are the problems of cream skimming and reduced attractiveness to investors. Furthermore, it is exceptionally difficult, even with a uniform product such as electric power, to get common carriage arrangements to work effectively. For obvious reasons a company in danger of losing customers has every incentive to attempt to charge high prices for the use of its pipeline networks. Arrangements in the water and sanitation sector are further complicated by quality 
issues. It is simply not possible to ensure that individual users receive the water actually put into the network to meet their needs or for a treatment company to receive the actual sewage or trade effluent it is contracted to treat.

The second advantage of disaggregation is that it provides more complete and transparent information about the industry and thus increases the scope and effectiveness of 'yardstick' or comparative competition. Yardstick competition simply means that the performance of one company (public or private) can be assessed by comparing it with other suppliers of the same service using a variety of performance criteria (product price, pipeline leakage levels, maintenance cost per kilometre of main, investment expenditure on standard infrastructure items, etc.). Such comparisons can act as 'informal' pressure on companies to improve efficiency or refrain from monopoly power abuses. For example, where independent companies are operating as separate links along the water delivery and waste removal chain, each would have an incentive to scrutinize the relative performance of their 'supplier'. Likewise, both shareholders and customers would have better information about the way their company was performing. Such informal comparative assessments exert some pressure on managers worried about their share prices, keen to attract new business or simply anxious to protect their reputation. No managers are happy to see their companies at the bottom of a published performance league table.

Comparative competition has also proved to be an effective formal tool used by economic regulators to set companies efficiency targets and establish allowable price increases. Importantly, such competition can be employed to help sustain utility performance after privatisation has occurred; it acts as a countervailing force against the natural tendency for monopolists to diverge from least-cost operating practices. It was, for example, employed to good effect when new price limits were established for the private water utilities in England and Wales (OfWat, 1994) and has also been successfully used in Chile to improve the efficiency of publicly owned and managed water suppliers.

The final advantage of disaggregation is that it reduces the scope for some forms of monopoly power abuse. One example here is the restricted ability to use investment in water infrastructure to enhance the developmental potential (and thus land values) of land owned directly by the water service company, an affiliated firm or a major shareholder. 


\section{The costs of disaggregation}

Whether these advantages of disaggregation actually produce enough benefits, in terms of performance improvements and reduced regulatory burden, to outweigh the costs involved, is in many circumstances highly debateable. If a disaggregated structure can only be achieved by breaking up the existing public sector utility, then the transaction costs could be considerable. These costs could include expenditure on realigning distribution pipes or sewerage systems, overcoming opposition from current managers and employees, and establishing enough information on which to create separate accounts.

In addition, disaggregated structures may result in lost economies of scale and scope. The former arise when the unit costs of provision fall as more customers are served, while the latter occur when it is cheaper to produce two goods (or services) together than it would be to provide each separately. Good data on the optimal operating scale for different segments of the water industry are typically not available in many countries. There is, however, enough international evidence to show that bulk supply generation and transmission services are subject to major scale economies. Moreover, spatially integrated bulk networks, capable of serving different demand centres from several supply sources (surface and ground) can reduce total supply capacity margins while increasing overall supply security. For this segment of the business it is then highly unlikely that the potential competitive advantages from having smaller scale operators would outweigh the technical efficiency advantages of large scale operations.

In the cases of local water distribution networks, sewerage systems, water and sewage treatment, the optimal operating scale appears to be much lower. UK evidence suggests that it could be below 1 million served customers, but the exact figure will be highly regionally specific (varying with population density, asset conditions and so forth). There may, therefore, be scope in large urban centres to have more than one company providing water and sanitation services. Disaggregation has, in fact, already occurred in Paris, with separate companies operating on either side of the Seine and two concessions have recently been let in Manila. It is worth pointing out that dividing provision in very large metropolitan areas not only allows some, albeit limited, comparative competition but it also makes it easier for local community and planning agencies to forge consultative links with the companies. 
A further, and in some countries critical, disadvantage of disaggregation is that it could reduce the interest of private-sector companies in participating in the enterprise at all. Alternatively their interest may only be secured at a greatly increased cost. The real dilemma is that all measures designed to reduce monopoly power also reduce the potential profitability of the private-sector companies. Countries or municipalities which desperately need an injection of private-sector capital may, quite understandably, decide that the short-term gains from the investments will outweigh the future potential problems of regulating a monopoly company. Indeed, they may be right to do so, because once major investments are made, the company becomes much more vulnerable to political and regulatory risk. Some political risks are, of course, quite unrelated to company behaviour, but private-sector managers are well aware that excessive profit taking and widespread customer dissatisfaction with prices and service standards will increase the probability of an unpleasant political and regulatory backlash. There are then some self-regulatory mechanisms at work which limit the exercise of monopoly power.

\section{Regulatory Regimes}

REGULATION IS OFTEN thought of purely as sets of commands issued by governments, which are designed to control behaviour, with accompanying 'police forces' and penalties for failure to obey. Regulation is actually much more than this. While undoubtedly there are command 'sticks', incentive 'carrots' also have a key role to play. In addition, it is not valid to assume that all regulation is designed to force private companies to act against their own self-interest in ways which further general public interests (or the interests of dominant political parties). Most regulation, in fact, only works effectively with the consent of the regulated, being based on an acceptance that the 'commands' are reasonable. There is a massive literature which argues that regulation is often demanded by private firms to increase their market, curb risks or reduce competition by creating barriers to entry for new firms or substitute products (Stigler, 1971). Another, possibly even more voluminous, literature suggests that even when regulatory systems are not designed to serve private interests, they are 'captured' by them. 
As early as 1955, for example, Bernstein (1955) was arguing that the regulatory commissions in the United States (regulating private electricity, gas and water utilities) were prone to act for the companies rather than for their customers.

The regulatory regime faced by potential private sector operators is, in a very real sense, the product of a bargaining process, the outcomes of which will very much depend on the resources (power) and needs of the various players. Government departments responsible for the water sector and private companies, including financial institutions, are not the only players. Other government agencies, political parties, current utility managers, labour unions and consumer organisations will all be among the stakeholders keen to ensure that private-sector involvement will serve, or at least not harm, their interests.

\section{The elements of a regulatory regime}

Four distinct elements are included in the regulatory regime:

- The general framework of laws, constitutional rules, policies and administrative structures within an economy, which while not developed with the water sector in mind, nevertheless impinge on its activities and affect the willingness of the private sector to participate in service provision. These include labour law, company taxation rules, currency controls, and the constitutional division of responsibilities between national, regional and local government.

- Water resource and environmental laws, water right allocation and protection mechanisms and the performance of any resource conservation or pollution control agencies;

- Specific water and sanitation sector regulation, including the legislation enabling private sector participation, the powers and capacity of any regulatory agencies, regulatory tools and mechanisms for public scrutiny and consultation;

- The individual contracts or licences under which the companies operate. 


\section{Competition in Alternative Industry Structures}

\begin{tabular}{|c|c|c|c|c|}
\hline Form of Competition & $\begin{array}{l}\text { O perating and } \\
\text { Maintenance } \\
\text { Contract }\end{array}$ & Concession & BOT & Divestment \\
\hline In the market & No & No & No & No \\
\hline $\begin{array}{l}\text { Entry: boundary and inset } \\
\text { competition }\end{array}$ & No & No & No & $\begin{array}{l}\text { Yes } \\
\text { (if common carriage, } \\
\text { insets and entry } \\
\text { allowed) }\end{array}$ \\
\hline For the market & Yes & $\begin{array}{l}\text { Yes } \\
\text { (but limited by } \\
\text { contract length) }\end{array}$ & Yes & No \\
\hline Capital market & No & \multicolumn{2}{|c|}{\begin{tabular}{c|c} 
Yes & Yes \\
(but limited for large conglomerates)
\end{tabular}} & Yes \\
\hline $\begin{array}{l}\text { Comparative (yardstick) } \\
\text { By regulator }\end{array}$ & $\underbrace{}_{\text {lif seve }}$ & $\begin{array}{l}\text { Yes } \\
\text { I large companies ar }\end{array}$ & $\begin{array}{l}\text { Yes } \\
\text { operating in the cc }\end{array}$ & $\mathrm{Itry)}_{\mathrm{Pes}} \stackrel{\text { Yes }}{\longrightarrow}$ \\
\hline $\begin{array}{l}\text { By independent } \\
\text { companies within } \\
\text { industry water use chain }\end{array}$ & Yes & $\begin{array}{l}\text { Yes } \\
\text { - lif allowed by in }\end{array}$ & $\begin{array}{c}\text { Yes } \\
\text { Iustry structure) }\end{array}$ & Yes \\
\hline
\end{tabular}

Figure 5. Sector structure has an important bearing on the regulatory burden to protect customer interests; competition can be an alternative to regulation. 
From this list of elements it can be readily appreciated that privatisation (other than very basic service contracts) is not a simple process.

There will be situations where some elements of the general framework of laws will need changing before any meaningful level of private-sector participation is feasible at all. More usually, unattractive elements in this framework will have to be overcome by, for example, settling for a low-risk type of private involvement, such as a basic management contract. Alternatively, it may be possible to incorporate explicit (and enforceable) safeguards for the private companies in specific sector laws or individual contracts.

Inevitably, water and sanitation companies are going to be particularly sensitive to regulations (or the absence of them) which govern water resources allocation and water pollution control. If existing regulatory systems cannot guarantee usage rights, protect the companies from costly changes in resource availability or quality, and safeguard them from the introduction of new environmental quality controls, then once again the private participants will demand protection within the contract terms. For example, 'cost pass through' arrangements could be put in place, which allow companies to increase water prices to cover any cost changes. Alternatively, the private operator could be relieved of obligations to maintain supplies or supply qualities when exogenous changes to the water resource occur.

\section{Regulatory tasks}

For reasons discussed earlier, unregulated water and sanitation companies are simply not an option. The list of regulatory tasks needed in an ideal world is potentially long (figure 4), particularly so for divestments and concessions. However, while some of these tasks may be desirable, the capacity of regulators to perform them, the costs involved and the willingness of the private companies to accept restrictions on their activities will all affect what it is practical to implement. As with most aspects of the privatisation process, a large dose of realism has to be injected into the design of sector-specific regulations and individual contracts.

By and large, private sector companies would prefer regulatory discretion (and thus regulatory risk) to be minimised and for the contract to be the major regulatory mechanism. Highly specific contract terms, setting out duties, performance targets, water price 
uprating rules, and dispute arbitration procedures, allow the companies to better predict the profitability of the venture and decide what it is worth paying to win the contract. Such contracts may also be advantageous for governments in that more bidders could be attracted and a better deal struck. In the case of long-term contracts, delicate judgments will have to be made about whether restricting the public sector's role of monitoring contract compliance is economically, politically and socially acceptable.

\section{Conclusions}

PRIVATE-SECTOR PARTICIPATION in the water and sanitation sector is not a general panacea.

The most commonly cited causes of the failure of state enterprises insulation from competitive incentives and political interference - do not magically vanish when private sector involvement occurs. In some countries, the need for private sector expertise and financial resources is compelling, but these will only be made available if it is profitable to do so. Where governments and customers have been unwilling or unable to pay for the desired level of services, major politically and socially difficult choices will have to be made. The private sector will certainly not be interested in participating unless cost recovery questions are addressed. Likewise, private companies will not act as depositories for the disguised unemployed unless they are paid to do so; increased productivity will involve significant labour shedding with all the accompanying political and social problems. Privatisation may provide the catalyst for needed sector reforms, but the decisions to make the reforms and accept the consequences are public-sector responsibilities.

Any privatisation of a public utility is a complex exercise, but the water and sanitation sector has several key characteristics which make the process particularly difficult. The overwhelming presence of monopoly may mean that the efficiency savings, which private-sector involvement is supposed to achieve, will not arise, unless, that is, the form of privatisation, industry structure and regulatory arrangements provide competitive incentives. 
In addition, the social, developmental and environmental importance of the water sector means that continued public regulation will be inevitable. Devising a regulatory regime which protects public interests while avoiding unpredictable political interference is a difficult task. The success of privatisation will, however, critically depend on how well this task is accomplished. 


\section{References}

Bernstein, M.A. (1955) Regulating Business by Independent Commission.

Princeton University Press, Princeton, N.J.

Bishop, M. and Green, M. (1995) Privatisation and Recession - The M iracle

Tested. CRI Discussion Paper 10, CIPFA, London.

Herrington, P. and Price, C. (1987) What Price Private Water. Public Finance Foundation, London.

Hoare Govett Asia Ltd. (1997) Eastern Water Resources Development and Management. ABN AMRO, Hoare Govett Asia Ltd., Hong Kong.

Idelovitch, E. and Ringskog, K. (1995) Private Sector Participation in Water Supply and Sanitation in Latin America. World Bank, Washington D.C.

Littlechild, S. (1986) Economic Regulation of Privatised Water Authorities. HMSO, London.

Martin, S. and Parker, D. (1997) The Impact of Privatisation: O wnership and Corporate Performance in the UK. Routledge, London.

OfWat (1994) Future Changes for Water and Sanitiation Services. Office of Water Services, Birmingham.

OfWat (1997) First Commercial Customer Switches Water Supplier. Press Release, 28th May. Office of Water Services, Birmingham.

Parker, D. (1997) Privatisation and Regulation: Some Comments on the UK Experience, Occasional Paper No. 5. CRI, CIPFA, London.

Parker, D. and Martin, S. (1997) Assessing the Impact of Privatisation on Company Efficiency, Occasional Paper No. 5 CRI, CIPFA, London.

Rees, J. (1989) Water Privatisation Research Papers. Dept. of Geography London School of Economics, London.

Stigler, G. (1971) The theory of economic regulation. Bell Journal of Economic and M anagement Science, Vol. 2, No.1, pp. 3-21.

Yarrow, G. (1989) Privatisation and Economic Performance in Britain.

Carnegie-Rochester Conference Series on Public Policy, Vol. 31, pp. 303-44. 
This brochure is printed on swan-marked paper.

The Nordic swan mark guides consumers to the most environmentally sound products. To acquire the swan symbol, producers must adhere to strict guidelines which are revised on an ongoing basis. This paper was produced according to these guidelines. 


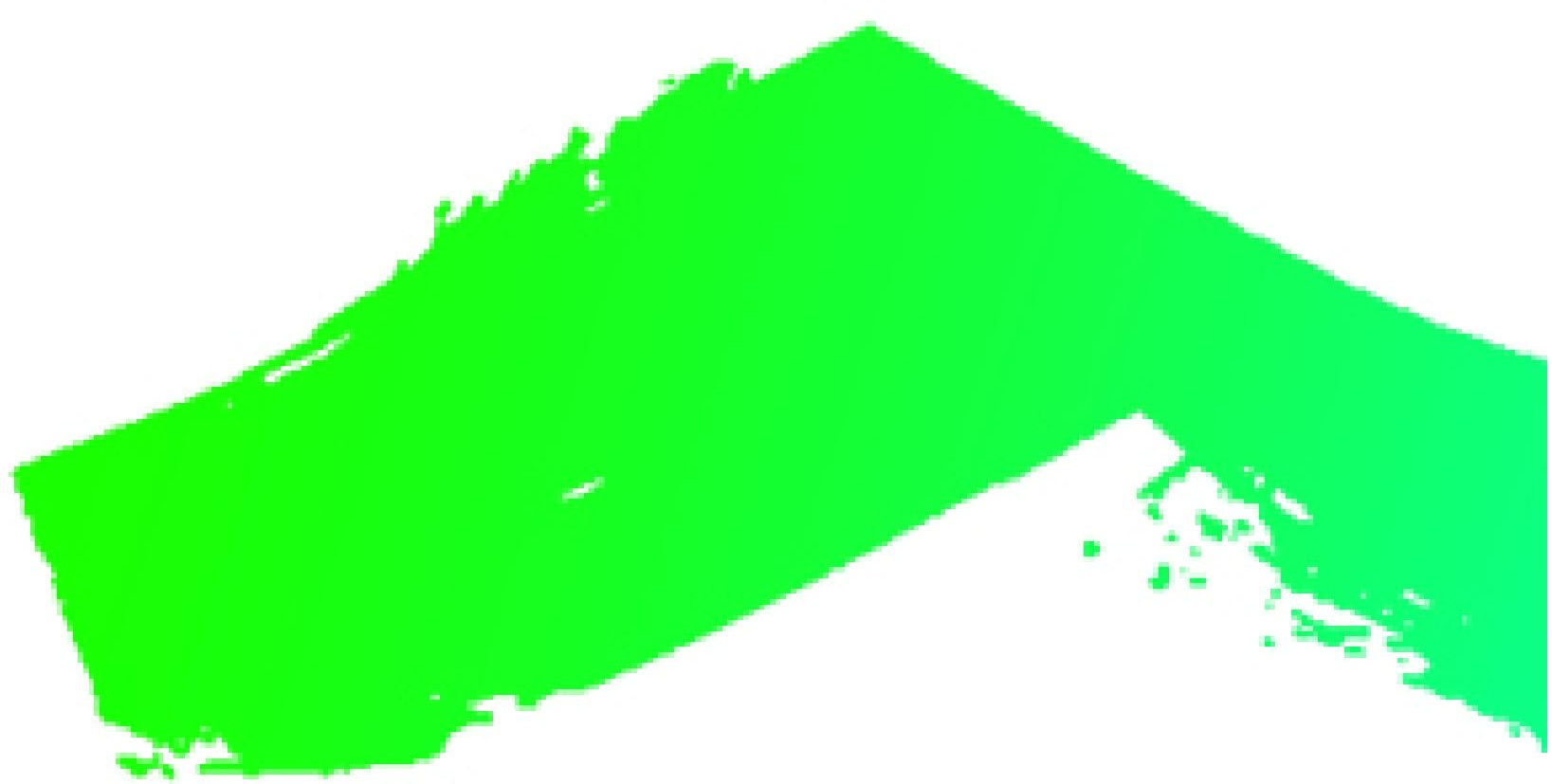

\section{Global Water Partnership}

GWP Secretariat, Sida, S-105 25 Stockholm, Sweden. Office: Sveavägen 24-26, Stockholm Telephone +46(0)86985000 Telefax+46(0)8 6985627 